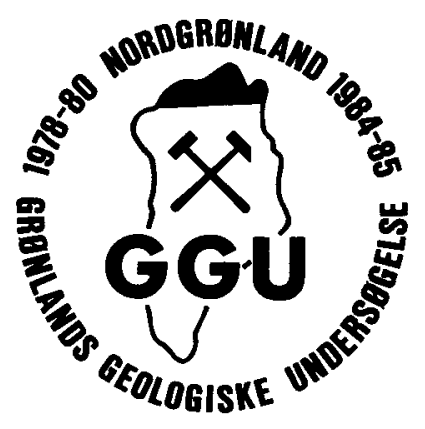

\title{
Archaean age and Proterozoic metamorphic overprinting of the crystalline basement at Victoria Fjord, North Greenland
}

\author{
Bent Tauber Hansen, Feiko Kalsbeek \\ and Paul Martin Holm
}

Zircon U-Pb and $\mathrm{Rb}-\mathrm{Sr}$ whole-rock isotope data show that the crystalline rocks at the head of Victoria Fjord, North Greenland, have Archaean ages (c. $3000 \mathrm{Ma}$ ), but that strong disturbance of the isotope systems has taken place later. $\mathrm{K}-\mathrm{Ar}$ analyses on hornblende show that the area underwent a phase of high-grade metamorphism during the Proterozoic, probably around $1850 \mathrm{Ma}$.

B. T. H., Institut für Mineralogie, Westfälische Wilhelms-Universität, Corrensstrasse 24, D-4400 Münster, West Germany. F. K., Grønlands Geologiske Unders $\varnothing$ gelse, $\emptyset$ ster Voldgade 10, DK-1350 Copenhagen K, Denmark.

P. M. H., Institut for Petrologi, Københavns Universitet, $\emptyset$ ster Voldgade 10, DK-1350 Copenhagen K, Denmark.

Large areas of the crystalline shield of Greenland consist of Archaean rocks, locally interrupted by Proterozoic intrusions, and commonly affected by Proterozoic tectonometamorphic activity (Kalsbeek, 1986; fig. 1). In North Greenland the crystalline basement is only exposed at the head of Victoria Fjord along the margin of the Inland Ice; elsewhere icetransported boulders of basement rocks are common in glacial deposits, and indicate the presence of crystalline rocks beneath the northern sector of the Inland Ice and probably also underlying the Middle Proterozoic to Lower Palaeozoic platform throughout North Greenland.

This report presents the results of U-Pb age determinations on zircons from two samples, $\mathrm{Rb}-\mathrm{Sr}$ whole-rock isotope data on two sample sets, and $\mathrm{K}$-Ar measurements on three hornblende concentrates, all from the basement rocks at the head of Victoria Fjord. The samples were collected in 1984 by Niels Henriksen and Hans F. Jepsen (GGU) and the following deseription of the field setting of the rocks is based on their field observations (Henriksen \& Jepsen, 1985). 


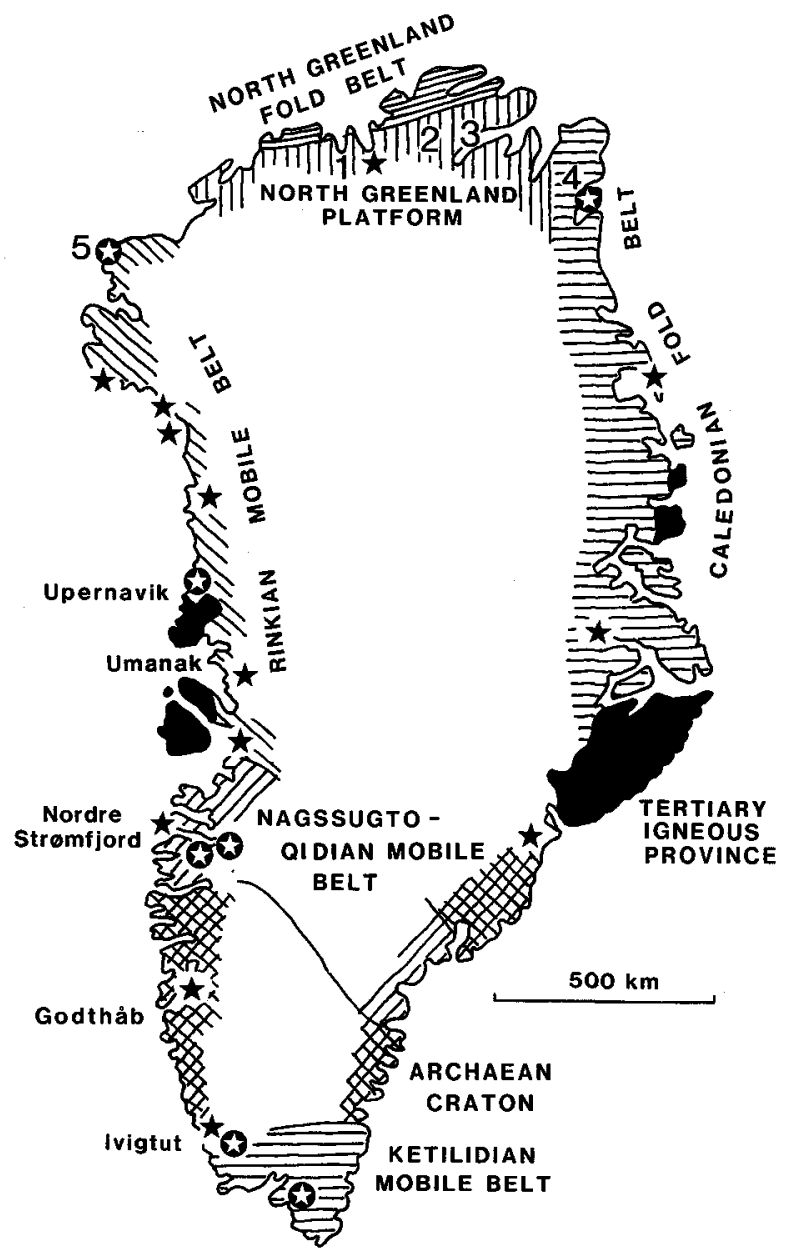

Fig. 1. The main tectonic units of Greenland, with localities of dated Archaean and Proterozoic rocks (black and white stars, respectively), after Kalsbeek (1986). Localities and rock units mentioned in the text are numbered. 1: Head of Victoria Fjord, where the samples for the present investigation were collected. 2: Sydpasset. 3: Independence Fjord. 4: Ingolf Fjord. 5: The Etah meta-igneous complex of Inglefield Land.

\section{The crystalline basement at Victoria Fjord}

Crystalline rocks outcrop at the head of Victoria Fjord over an area of $c .20 \times 30 \mathrm{~km}$, centred at approximately $81^{\circ} 30^{\prime} \mathrm{N} 45^{\circ} 30^{\prime} \mathrm{W}$. They are unconformably overlain by flat lying sediments of the Morænes $\varnothing$ (late Proterozoic) and Portfjeld (Cambrian) Formations, indicating a Precambrian age for the basement. The exposed rocks are dominated by homogeneous leucocratic orthogneisses with variable intensity of foliation and grading locally into almost granitic rocks. The rocks are often migmatitic; they may contain thin quartzofeldspathic veins conformable to the foliation of the gneisses, and pegmatites occur locally both as conformable veins and as later cross-cutting dyke-like bodies. The orthogneisses contain numerous sheets of black amphibolite, up to $30 \mathrm{~m}$ wide, which locally are discordant to the gneissic foliation and are thought to represent former basic intrusions. Supracrustal rocks have been observed at a number of localities within the orthogneisses. They are dominated by foliated amphibolite bands together with biotite-rich mica schists and, at one lo- 
cality, by a coarsely crystalline marble layer. Their thickness varies up to c. $50 \mathrm{~m}$. At one locality an irregularly shaped body of late leucocratic quartz diorite was found with locally sharp and also locally gradational boundaries with the surrounding foliated orthogneiss.

Most of the samples studied were collected at the south-western corner of a nunatak near the edge of the Inland Ice $\left(81^{\circ} 31^{\prime} \mathrm{N} 44^{\circ} 45^{\prime} \mathrm{W}\right)$; one sample used for hornblende K-Ar dating (314237) comes from another nunatak $\left(81^{\circ} 25^{\prime} \mathrm{N} 45^{\circ} 05^{\prime} \mathrm{W}\right)$.

\section{Zircon U-Pb data}

Zircon concentrates were prepared from one sample of the homogeneous orthogneisses (GGU 312632) and one sample of the late quartz diorite (GGU 312635). The gneiss sample consists of about equal proportions of quartz, plagioclase (oligoclase) and K-feldspar, with some biotite (partly chloritised), and accessory apatite, epidote, opaque minerals, sphene and zircon. The quartz diorite consists mainly of clouded plagioclase (andesine) with quartz and biotite (strongly chloritised) and accessory apatite, opaque minerals and zircon. This sample has a well preserved igneous texture.

\section{Analytical procedures}

The zircon U-Pb work was carried out at the Zentrallaboratorium für Geochronologie at the University of Münster, West Germany. The chemical procedures for the zircon analyses followed the method of Krogh (1973). A more detailed description of the method applied is given by Persson et al. (1983). The isotopic measurements were carried out on a Teledyne 12 " $90^{\circ}$ solid-source mass-spectrometer. For the common lead correction an isotopic composition corresponding to the upper concordia intercept ages, computed according to the model of Stacey \& Kramers (1975), was employed. The assigned analytical errors $(2 \sigma)$ based on replicate analyses are $0.7 \%$ for the ${ }^{207} \mathrm{~Pb} /{ }^{235} \mathrm{U}$ ratios and $0.4 \%$ for the ${ }^{206} \mathrm{~Pb} /{ }^{238} \mathrm{U}$ and ${ }^{207} \mathrm{~Pb} /{ }^{206} \mathrm{~Pb}$ ratios. Throughout this paper we use the decay constants recommended by the IUGS (Steiger \& Jäger, 1977), and the precisions of the age results are given at the two sigma (95\%) level of confidence. The least squares method of York (1969) was used for the calculation of the regression lines.

\section{Results}

Most of the zircons of gneiss sample 312632 are elongate prismatic with a length-width ratio of 3 to 4 , and have a light grey colour. They mostly have round edges and blunt terminations. Other grains are more strongly rounded and have a brownish colour. Only a few grains have cracks, but many display corroded surfaces. The proportion of long prismatic to rounded grains is about 2 to 1 , slightly increasing with decreasing grain size.

Analytical data for five grain-size fractions are listed in Table 1 and shown graphically in fig. 2A. The zircons are highly discordant and, apart from the size fraction $<40 \mu$, show little variation in their isotopic composition. There is no significant correlation between the uranium contents of the different analysed fractions and their grain size (Table 1), a phenomenon often found in other zircons from Archaean rocks (Hansen $e t$ al., in press). The data points do not define an ideal chord (fig. 2A) but scatter around a reference line (MSWD: 2.3) with an upper intercept corresponding to an age of $2863_{-30}^{+32} \mathrm{Ma}$, and a lower intercept at $72 \pm 44 \mathrm{Ma}$. The regression line is strongly affected by the fraction $<40 \mu$; if this point is omitted from the regression calculation the upper intercept age becomes $c .2750 \mathrm{Ma}$. 

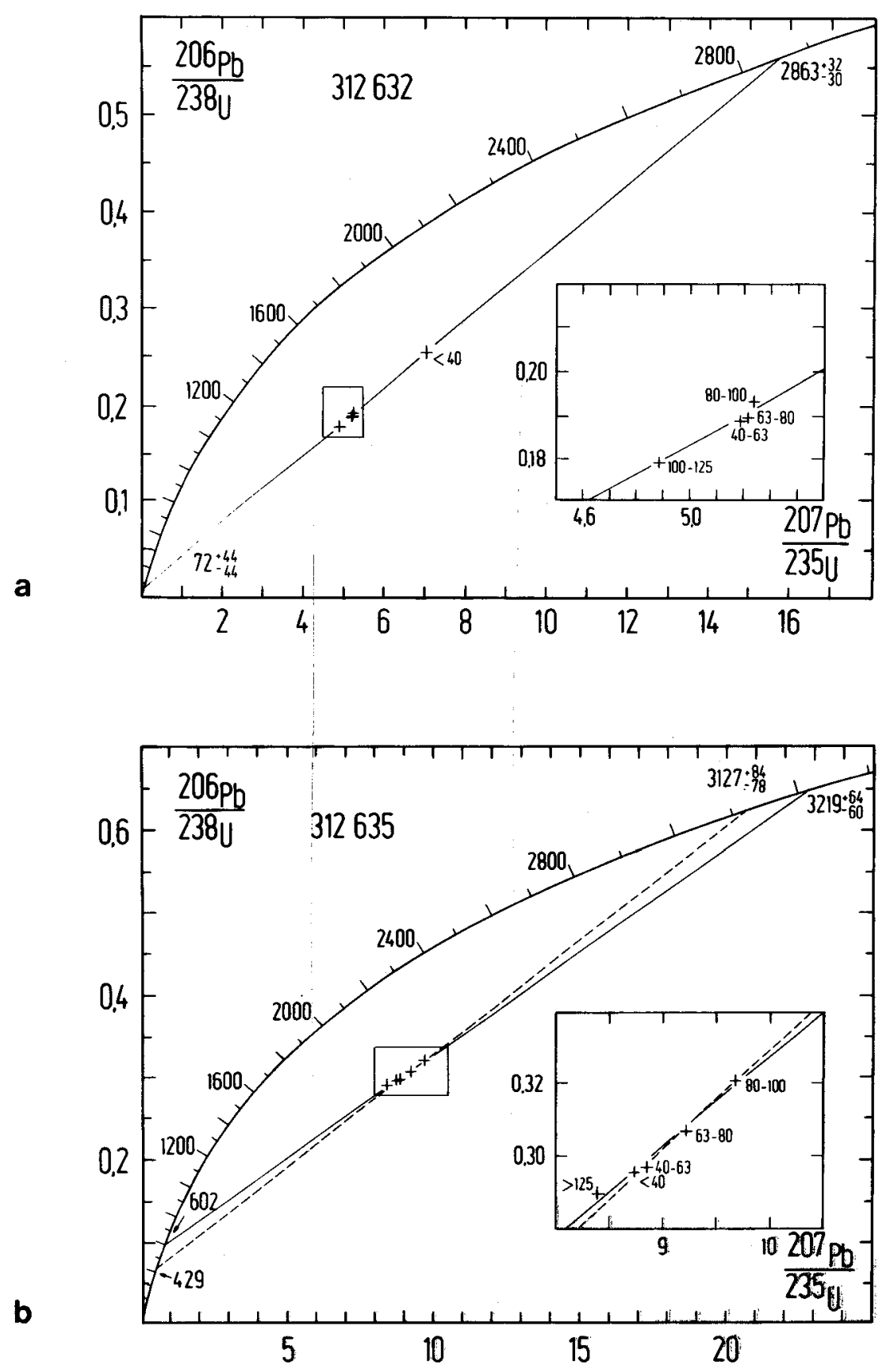

Fig. 2. Zircon concordia plots for samples 312632 and 312635 from the Victoria Fjord basement. The upper and lower intersection ages and the ages shown along the concordia line are in $\mathrm{Ma}$, and the small numbers that identify the data points give the zircon size fractions in microns. 
Table 1. U-Pb analytical data on zircons from the crystalline basement at the head of Victoria Fjord, North Greenland

\begin{tabular}{|c|c|c|c|c|c|c|c|c|c|c|c|}
\hline \multirow{2}{*}{$\begin{array}{l}\text { GGU sample } \\
\text { No \& sieve } \\
\text { fraction } \\
\text { in } \mu \mathrm{m}\end{array}$} & \multirow{2}{*}{$\begin{array}{l}\text { g sample } \\
\text { analysed }\end{array}$} & \multicolumn{3}{|c|}{ Observed atomic ratios } & \multirow[t]{2}{*}{$\begin{array}{c}\mathrm{U} \\
\mathrm{ppm}\end{array}$} & \multirow[t]{2}{*}{$\begin{array}{l}\mathbf{P b}_{\text {rad }} \\
\text { ppm }\end{array}$} & \multirow[t]{2}{*}{$\begin{array}{r}{ }^{206} \mathrm{~Pb}_{\text {rad }} \\
\mathrm{n} \mathrm{mol} / \mathrm{g}\end{array}$} & \multicolumn{3}{|c|}{$\begin{array}{l}\text { Atomic ratios corrected for } \\
\text { blank }{ }^{*} \text { and common } \mathrm{Pb}\end{array}$} & \multirow{2}{*}{$\begin{array}{c}\text { Apparent age } \\
\qquad \mathrm{Ma} \\
\frac{{ }^{207} \mathrm{~Pb}}{20 \mathrm{~Pb}}\end{array}$} \\
\hline & & ${ }^{206} \mathrm{~Pb}$ & ${ }^{206} \mathrm{~Pb}$ & ${ }^{204} \mathrm{~Pb}$ & & & & $\frac{206 \mathrm{~Pb}}{{ }^{238} \mathrm{U}}$ & $\frac{{ }^{207} \mathrm{~Pb}}{{ }^{235} \mathrm{U}}$ & $\frac{{ }^{2077} \mathrm{~Pb}}{206 \mathrm{~Pb}}$ & \\
\hline \multicolumn{12}{|l|}{$G G U 312632$} \\
\hline$<40$ & 0.0060 & 0.79183 & 0.41810 & 54.1 & 1074 & 339 & 1137 & 0.25369 & 7.031 & 0.20100 & 2834 \\
\hline $40-63$ & 0.0064 & 0.17843 & 0.23280 & 349 & 2912 & 609 & 2296 & 0.18900 & 5.187 & 0.19904 & 2818 \\
\hline $63-80$ & 0.0040 & 0.18112 & 0.23279 & 352 & 1875 & 395 & 1484 & 0.18980 & 5.216 & 0.19932 & 2821 \\
\hline $80-100$ & 0.0048 & 0.17553 & 0.22899 & 362 & 1527 & 326 & 1232 & 0.19339 & 5.237 & 0.19642 & 2797 \\
\hline $100-125$ & 0.0038 & 0.18361 & 0.23162 & 349 & 1603 & 319 & 1197 & 0.17909 & 4.886 & 0.19786 & 2809 \\
\hline \multicolumn{12}{|l|}{$G G U 312635$} \\
\hline$<40$ & 0.0051 & 0.13858 & 0.23977 & 457 & 944 & 308 & 1164 & 0.29555 & 8.739 & 0.21444 & 2939 \\
\hline $40-63$ & 0.0056 & 0.12723 & 0.23873 & 514 & 980 & 321 & 1214 & 0.29695 & 8.855 & 0.21626 & 2953 \\
\hline $63-80$ & 0.0060 & 0.12088 & 0.23970 & 531 & 908 & 306 & 1162 & 0.30671 & 9.218 & 0.21799 & 2966 \\
\hline $80-100$ & 0.0054 & 0.11711 & 0.23792 & 605 & 930 & 329 & 1244 & 0.32066 & 9.678 & 0.21890 & 2973 \\
\hline$>125$ & 0.0074 & 0.14118 & 0.23431 & 483 & 1034 & 331 & 1249 & 0.28969 & 8.397 & 0.21023 & 2907 \\
\hline
\end{tabular}

Composition of lead used for blank correction: ${ }^{206} \mathrm{~Pb} /{ }^{204} \mathrm{~Pb}=18.7,{ }^{207} \mathrm{~Pb} /{ }^{204} \mathrm{~Pb}=15.63,{ }^{208} \mathrm{~Pb} /{ }^{204} \mathrm{~Pb}=$ 38.63. The composition of common lead used for the correction follows the model of Stacey \&

Kramers (1975).

The ${ }^{207} \mathrm{~Pb} /{ }^{206} \mathrm{~Pb}$ ages for the different zircon fractions are in the order of $2800 \mathrm{Ma}$, and this must be regarded as the minimum age of zircon formation in sample 312632 .

The zircons of sample 312635 (the late quartz diorite) have a light brown colour and a length-width ratio of about 2 . All grains show cracks and rounded terminations, and most have pitted surfaces. In the two fractions $<63 \mu$ a minor proportion of the grains are transparent, free of inclusions and are elongate prismatic with well developed terminations.

The data of five analysed size fractions scatter around a chord (MSWD: 2.9) which intersects with concordia at $3219_{-60}^{+64} \mathrm{Ma}$ and $602 \pm 95 \mathrm{Ma}$ (fig. $2 \mathrm{~B}$ ). The coarsest fraction, which is also the most uranium-rich (Table 1), yields the most discordant point, whereas the other fractions show increasing discordance with decreasing grain size. If the data point for the coarsest fraction is omitted from the calculation of the discordia, an upper intersection age of $3127_{-78}^{+84} \mathrm{Ma}$ is obtained. Because of the high discordance of the data points the extended extrapolation does not allow precise dating of the rock. However, the ${ }^{207} \mathrm{~Pb} /{ }^{206} \mathrm{~Pb}$ ages show lead components as old as $2973 \mathrm{Ma}$ (Table 1) which must be regarded as a minimum age for the formation of the zircons.

\section{Discussion}

The zircon U-Pb data show beyond doubt that the rocks in question have Archaean ages. A more detailed interpretation of the data is not straightforward, however. The field evidence shows that the late quartz diorite (GGU 312635) is younger than the homogeneous foliated orthogneisses (GGU 312632). Nevertheless, the orthogneiss zircons yield a younger age (c. $2860 \mathrm{Ma}$ ) than those of the leucogranite (c. $3200 \mathrm{Ma}$ ). This shows that the zircon ages cannot be taken at face value. It seems likely that the zircon $\mathrm{U}-\mathrm{Pb}$ systems have undergone a 
complex multistage history, with different episodes of lead loss and/or new growth of zircon, to give rise to this inconsistency. Under such circumstances the information obtained from the zircon $\mathrm{U}-\mathrm{Pb}$ data is considerably reduced in detail. The Rb-Sr analyses reported in the next section were carried out to obtain further information on the history of the rocks.

\section{Rb-Sr whole-rock data}

$\mathrm{Rb}-\mathrm{Sr}$ isotope analyses were carried out on two sets of orthogneiss samples collected within a short distance. One set consists of slightly banded orthogneisses, whereas the gneisses of the other set are more homogeneous. The latter were collected from large, angular, ice-transported boulders, apparently derived from a near-by source.

\section{Analytical procedure}

The Rb-Sr isotope work was carried out at the Institut for Petrologi, University of Copenhagen. Strontium was separated from the samples by conventional ion-exchange techniques, and its isotopic composition was measured with a Varian Mat solid source mass-spectrometer with on-line data reduction. The ${ }^{87} \mathrm{Sr} /{ }^{86} \mathrm{Sr}$ ratios were normalised and calibrated against a value of 0.7080 for the Eimer and Amend $\mathrm{SrCO}_{3}$ standard. $\mathrm{Rb} / \mathrm{Sr}$ ratios were measured by XRF spectrometry and calibrated against USGS rock standards. The isochron calculations were performed by the McIntyre et al. (1966) method, model 1 , using the following (1o) precisions: $1 \%$ for the ${ }^{87} \mathrm{Rb} /{ }^{86} \mathrm{Sr}$ ratios and 0.0002 for the ${ }^{87} \mathrm{Sr} /{ }^{86} \mathrm{Sr}$ ratios. The errors associated with the age and initial ${ }^{87} \mathrm{Sr} /{ }^{86} \mathrm{Sr}$ ratios were calculated by multiplying the McIntyre model 1 errors with the square root of the MSWD values obtained.

Table 2. Rb-Sr isotope data for granitic gneisses in the crystalline basement at the head of Victoria Fjord, North Greenland

\begin{tabular}{lrlll}
\hline Sample No. & $\mathrm{Rb}$ & $\mathrm{Sr}$ & ${ }^{87} \mathrm{Rb} /{ }^{86} \mathrm{Sr}$ & ${ }^{87} \mathrm{Sr} /{ }^{86} \mathrm{Sr}$ \\
\hline A 312617 & 118 & 598 & 0.568 & 0.7259 \\
312620 & 96 & 441 & 0.631 & 0.7315 \\
312621 & 107 & 361 & 0.862 & 0.7433 \\
312622 & 96 & 351 & 0.786 & 0.7385 \\
312623 & 156 & 257 & 1.746 & 0.7891 \\
312624 & 139 & 368 & 1.078 & 0.7473 \\
312627 & 74 & 460 & 0.462 & 0.7239 \\
312628 & 60 & 453 & 0.383 & 0.7227 \\
312630 & 111 & 139 & 2.295 & 0.8050 \\
B 312643 & 125 & 345 & 1.035 & 0.7472 \\
312644 & 98 & 305 & 0.928 & 0.7447 \\
312647 & 108 & 376 & 0.824 & 0.7433 \\
312650 & 113 & 287 & 1.143 & 0.7539 \\
312651 & 106 & 409 & 0.743 & 0.7400 \\
312652 & 85 & 382 & 0.637 & 0.7335 \\
\hline
\end{tabular}

A: slightly inhomogeneous orthogneisses (sample set 1); B: homogeneous orthogneisses (sample set 2). $\mathrm{Rb}$ and $\mathrm{Sr}$ (in ppm, by XRF) \pm c. $5-10 \%$. Precisions for ${ }^{87} \mathrm{Rb}{ }^{86} \mathrm{Sr}$ and ${ }^{87} \mathrm{Sr}{ }^{86} \mathrm{Sr}$ are estimated at c. $1 \%$ and c. $0.0002(1 \sigma)$, respectively. 
Fig. 3. Rb-Sr isochron plot for gneisses from the Victoria Fjord basement. The dots represent slightly banded gneisses of sample set 1 and the crosses the more homogeneous gneisses of sample set 2 (see the text).

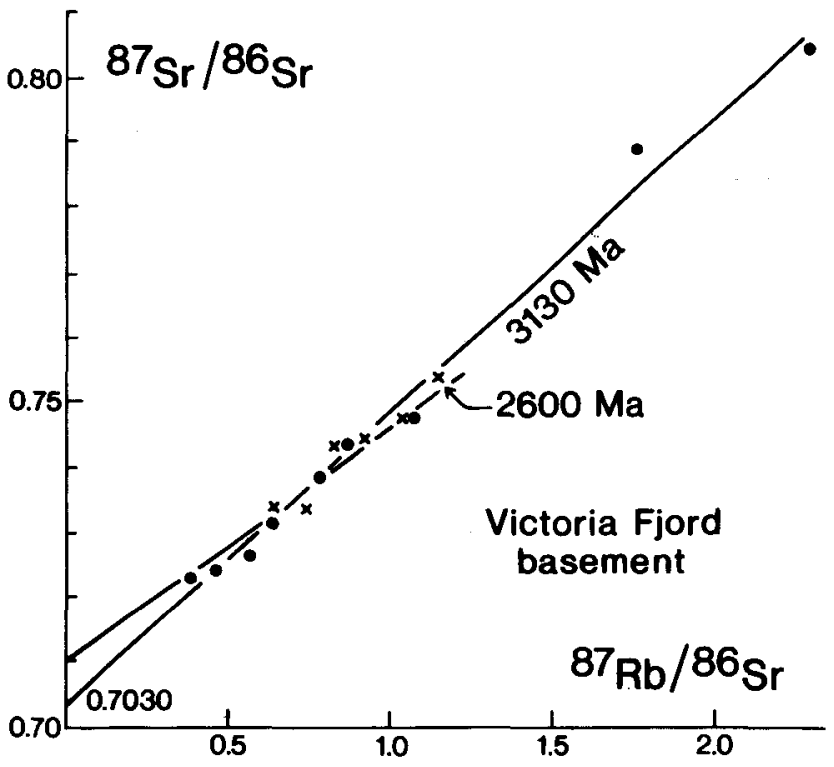

\section{Results}

The samples of the banded gneisses of the first set have a relatively wide range in $\mathrm{Rb} / \mathrm{Sr}$ ratios and nine samples were selected for $\mathrm{Sr}$-isotope measurements (Table 2). They provide a poorly fitted isochron (MSWD 44) giving an age of $3130 \pm 380 \mathrm{Ma}$ and an initial ${ }^{87} \mathrm{Sr} /{ }^{86} \mathrm{Sr}$ ratio $\left(\mathrm{Sr}_{\mathrm{i}}\right)$ of $0.7030 \pm 0.0039$ (fig. 3).

The more homogeneous gneisses from the second sample set have a narrower range of $\mathrm{Rb} / \mathrm{Sr}$ ratios. Six samples were selected for $\mathrm{Sr}$-isotopic analysis; they yield a poor isochron (MSWD 21). The age associated with this isochron is very poorly defined: $2600 \pm 670 \mathrm{Ma}$, $\mathrm{Sr}_{\mathrm{i}} 0.7106 \pm 0.0080$, partly because of the scatter about the isochron and partly because of the restricted range in ${ }^{87} \mathrm{Rb} /{ }^{86} \mathrm{Sr}$ ratios. A regression of all samples from both sets yields an age of $3120 \pm 310 \mathrm{Ma}, \mathrm{Sr}_{\mathrm{i}} 0.7034 \pm 0.0033$ and MSWD 36 .

\section{Discussion}

Because of the large scatter of the Rb-Sr isotope data about the isochrons, the ages obtained are poorly defined. However, the data confirm the Archaean age of the rocks derived from the zircon U-Pb measurements.

The scatter itself is consistent with a strong disturbance of the isotope systems in the rocks after their initial formation, as already suggested by the zircon U-Pb data. Such later disturbance often leads to a lowering of the $\mathrm{Rb}-\mathrm{Sr}$ isochron ages, and sample sets with a narrow range of $\mathrm{Rb} / \mathrm{Sr}$ ratios commonly yield lower apparent ages, and higher $\mathrm{Sr}_{\mathrm{i}}$ values, than sample sets with a wider range of $\mathrm{Rb} / \mathrm{Sr}$ ratios (Kalsbeek \& Pidgeon, 1980). The lower apparent age obtained for the homogeneous orthogneisses is in agreement with this behaviour.

It is not possible from the $\mathrm{Rb}-\mathrm{Sr}$ data to deduct the time of this disturbance. However, major tectonometamorphic events in the Greenland shield took place in the late Archaean, un- 
til c. $2600 \mathrm{Ma}$, and during the Proterozoic, around 1850 Ma ago (Kalsbeek \& Pidgeon, 1980; Kalsbeek et al. 1984), and one or both of these may be responsible for the isotopic disturbances observed in the investigated rocks. In rocks of the Archaean craton which have been affected by late Archaean events, but not by Proterozoic metamorphism, isochron relationships are normally much better preserved (resulting in lower MSWD values) than in Archaean rocks in areas affected by Proterozoic metamorphism (Kalsbeek \& Pidgeon, 1980; Kalsbeek, 1981). The high MSWD values, from 20 to 45, obtained for the gneisses from the Victoria Fjord area, suggest therefore that the isotopic disturbance in question is due to a Proterozoic rather than a late Archaean event. K-Ar mineral analyses (next section) have been carried out to test this impression.

\section{K-Ar hornblende data}

K-Ar analyses were carried out on hornblende concentrates from three samples of the amphibolites that form sheets in the gneisses, and that are thought to represent former intrusions (see above). The analytical work was done at the Institut for Petrologi, University of Copenhagen; the analytical procedures have been described by Pedersen \& Holm (1983). The data obtained are given in Table 3.

\section{Results and discussion}

The apparent ages calculated from the analytical data are $1983 \pm 30 \mathrm{Ma}, 1827 \pm 27 \mathrm{Ma}$, and $1903 \pm 40 \mathrm{Ma}$. Two of these are within error the same as the age for the peak of Proterozoic metamorphism in the Nagssugtoqidian and Rinkian mobile belts, $1880 \pm 50 \mathrm{Ma}$, obtained by Kalsbeek et al. (1984), and it is thus natural to correlate the K-Ar ages with a phase of metamorphism roughly contemporaneous with the Proterozoic metamorphism farther south. It appears likely that this metamorphism was the main cause of the disturbance of the zircon $\mathrm{U}-\mathrm{Pb}$ and whole-rock $\mathrm{Rb}-\mathrm{Sr}$ isotope systems noted above. The third $\mathrm{K}-\mathrm{Ar}$ date is slightly higher $(1983 \pm 30 \mathrm{Ma})$. This may be due to a minor proportion of radiogenic argon not expelled during the Proterozoic metamorphism, or to the presence of some 'excess' argon from foreign sources incorporated during the metamorphism.

Table 3. $K-A r$ isotope data for three hornblende concentrates from amphibolite sheets in the crystalline basement at the head of Victoria Fjord, North Greenland

\begin{tabular}{lcccc}
\hline Sample No. & $\begin{array}{c}\mathrm{K} \\
\text { weight } \%\end{array}$ & $\begin{array}{c}\mathrm{Ar} \\
10^{-10} \mathrm{~mol} / \mathrm{g}\end{array}$ & $\begin{array}{c}\mathrm{Ar}_{\mathrm{rad}} \\
\%\end{array}$ & Apparent age Ma \\
\hline 312633 & 0.607 & 38.00 & 81.47 & $1983 \pm 30$ \\
312634 & 0.754 & 41.35 & 81.10 & $1827 \pm 27$ \\
314237 & 0.889 & 52.06 & 83.66 & $1903 \pm 40$ \\
\hline
\end{tabular}

Estimated precisions: $\mathrm{K}-c .0 .8 \%$, total $\mathrm{Ar}-c .0 .2 \%$, and radiogenic $\operatorname{Ar}\left(\mathrm{Ar}_{\mathrm{rad}}\right)-c .0 .6 \%$, all relative to the measured concentrations. 


\section{Regional correlation}

The presence of Archaean rocks in the basement beneath the North Greenland platform has earlier been suggested by Kalsbeek \& Jepsen (1980) from a Rb-Sr isotope study of icetransported boulders from Independence Fjord (locality 3, fig. 1) and of samples from a giant gneiss inclusion within a Proterozoic dolerite at Sydpasset (loc. 2, fig. 1). Later (probably Proterozoic) disturbance of the $\mathrm{Rb}$-Sr isotope systems of these rocks was evident, however, and the Rb-Sr data did not, therefore, give reliable age information. The most important result of the present investigation is that it provides definitive proof of the existence of Archaean rocks in northernmost Greenland, and of the overprinting of these rocks by a phase of Proterozoic metamorphism.

The structure of the northernmost part of the crystalline shield of Greenland is not clear. Fig. 1 shows the presence of proven Archaean rocks (black stars) north of the Archaean craton of South Greenland. The area north of Upernavik in West Greenland contains an Archaean basement, overlain, in part, by Proterozoic supracrustal rocks (Kalsbeek, 1986). However, in northernmost West Greenland (loc. 5, fig. 1) the Etah meta-igneous complex is of Proterozoic age ( $c .1850 \mathrm{Ma}$ ), and according to the Rb-Sr evidence these rocks probably represent newly formed Proterozoic crust, and not reworked Archaean material (P. R. Dawes, F. Kalsbeek and O. Larsen, unpublished data). Equally, in northernmost East Greenland, near Wegener Øer in Ingolf Fjord (loc. 4, fig. 1), Proterozoic rocks have been found (c. 2000 Ma, zircon U-Pb data, R. T. Pidgeon, personal communication, 1981). The Rb-Sr isotope systems in these rocks are strongly disturbed (F. Kalsbeek, unpublished data), probably during the Caledonian orogeny. Here also, there is no isotopic evidence to suggest that these rocks might be reworked Archaean material.

Farther south in East Greenland, undoubted Archaean rocks have again been found (e.g. Steiger et al., 1976; for summary see Kalsbeek, 1981). Because of the lack of exposed crystalline rocks over most of North Greenland it is uncertain whether the rocks of Victoria Fjord form the extension of the Archaean basement beneath the Rinkian and Caledonian fold belts, or whether they are separated from these by an area of Proterozoic crust.

\section{References}

Hansen, B. T., Higgins, A. K. \& Borchardt, B. in press: Archaean U-Pb zircon ages from the Scoresby Sund region, East Greenland. Rapp. Gronlands geol. Unders.

Henriksen, N. \& Jepsen, H. F. 1985: Precambrian crystalline basement at the head of Victoria Fjord, North Greenland. Rapp. Grønlands geol. Unders. 126, 11-16.

Kalsbeek, F. 1981: The northward extent of the Archaean basement of Greenland - a review of Rb-Sr whole-rock ages. Precambrian Res. 14, 203-219.

Kalsbeek, F. 1986: The tectonic framework of the Precambrian shield of Greenland. A review of new isotopic evidence. Rapp. Grønlands geol. Unders. 128, 55-64.

Kalsbeek, F. \& Jepsen, H. F. 1980: Preliminary Rb-Sr isotope evidence on the age and metamorphic history of the North Greenland crystalline basement. Rapp. Grønlands geol. Unders. 99, 107-110.

Kalsbeek, F. \& Pidgeon, R. T. 1980: The geological significance of Rb-Sr whole-rock isochrons of polymetamorphic Archaean gneisses, Fiskenæsset area, southern West Greenland. Earth planet. Sci. Lett. 50, 225-237. 
Kalsbeek, F., Taylor, P. N. \& Henriksen, N. 1984: Age of rocks, structures, and metamorphism in the Nagssugtoqidian mobile belt, West Greenland - field and Pb-isotope evidence. Can. J. Earth Sci. 21, 1126-1131.

Krogh, T. E. 1973: A low-contamination method for hydrothermal decomposition of zircon and extraction of $\mathrm{U}$ and $\mathrm{Pb}$ for isotopic age determinations. Geochim. cosmochim. Acta 37, 485-494.

McIntyre, G. A., Brooks, C., Compston, W. \& Turek, A. 1966: The statistical assessment of Rb-Sr isochrons. J. geophys. Res. 71, 5459-5468.

Pedersen, S. A. S. \& Holm, P. M. 1983: The significance of a Middle Devonian K/Ar age of an intrusive rock in the southern part of the North Greenland fold belt. Bull. geol. Soc. Denmark 31, 121-127.

Persson, P.-O., Wahlgren, C.-H. \& Hansen, B. T. 1983: U-Pb ages of Proterozoic metaplutonics in the gneiss complex of southern Värmland, south-western Sweden. Geol. Fören. Stockholm Förh. 105, $1-8$.

Stacey, J. S. \& Kramers, J. D. 1975: Approximation of terrestrial lead isotope evolution by a two-stage model. Earth planet. Sci. Lett. 26, 207-221.

Steiger, R. H. \& Jäger, E. 1977: Subcommission on Geochronology: Convention on the use of decay constants in geo- and cosmochronology. Earth planet. Sci. Lett. 36, 359-362.

Steiger, R. H., Harnik-Soptrajanova, G., Zimmermann, E. \& Henriksen, N. 1976: Isotopic age and metamorphic history of the banded gneiss at Danmarkshavn, East Greenland. Contr. Miner. Petrol. 57, 1-24.

York, D. 1969: Least squares fitting of a straight line with correlated errors. Earth planet. Sci. Lett. 5, 320-324. 